\title{
A Review of Epidemiologic Studies of the Health of Gulf War Women Veterans
}

\author{
Steven S. Coughlin ${ }^{1,2 *}$, Maxine Krengel ${ }^{3}$, Kimberly Sullivan ${ }^{4}$, Penny F. Pierce ${ }^{5}$, Vahé Heboyan ${ }^{1}$, Lt Col \\ Candy Wilson ${ }^{6}$
}

${ }^{1}$ Department of Clinical and Digital Health Sciences, Augusta University, Augusta, GA

${ }^{2}$ Charlie Norwood VA Medical Center, Augusta, GA

${ }^{3}$ Boston Veterans Administration Healthcare System, Boston, MA

${ }^{4}$ Boston University School of Public Health, Boston, MA

${ }^{5}$ Uniformed Services University Graduate School of Nursing, Bethesda, MA

${ }^{6}$ Malcolm Grow Medical Clinics and Surgery Center at Joint Base-Andrews, MD

*Corresponding author: Dr. Steven S. Coughlin, Associate Professor, Department of Clinical and Digital Health Sciences, College of Allied Health Sciences, Augusta University, Augusta, GA 30912, 1120 15th Street, EC-4324, Tel: (706) 721-4643;

E-mail: scoughlin@augusta.edu

\begin{abstract}
Introduction: In the 25 years since the 1990-1991 Gulf War (GW), studies have evaluated Gulf War Illness (GWI), sometimes referred to as medically unexplained multi symptom illness, and other medical and neurological conditions in women GW veterans.

Materials and Methods: In this article, we review epidemiologic studies of the health of women who served in the 1990-1991 GW based upon bibliographic searches in PubMed and CINAHL with relevant search terms through September 2015.

Results: A total of 56 articles were identified in the bibliographic searches. By screening abstracts or full-text articles, a total of 21 relevant studies were identified. Results from some studies, but not all, suggest that GWI is more common in women GW veterans than their male counterparts. Few studies of GW veterans focused on women's health. A small number of studies suggested excess rates of woman's health problems, e.g., breast cysts, abnormal Papanicolaou (Pap) smears, yeast infections, and bladder infections. Several studies have identified significantly elevated rates of birth defects and adverse reproductive outcomes among GW veterans. However, findings have varied with different study designs and sample sizes, with some studies showing elevated risks of stillbirths, miscarriages, and/or birth defects and others have not. In some studies, participants reported increased risks of ectopic pregnancies and spontaneous abortions.

Conclusion: Further research is needed to provide a comprehensive picture of the health of women GW veterans and to examine a broad range of women's health issues including adverse reproductive outcomes. Some deployment-related health problems only become apparent decades later and other conditions may worsen or improve over time. Assessments are needed of current health status, changes in health symptoms and conditions over time, and possible differences in health outcomes associated with specific experiences and exposures during the war. Future studies would be strengthened by assessing GWI symptom patterns that may be specific to women veterans, examine diagnosed medical conditions among women veterans, and evaluate changes in women's health over time, including changes potentially associated with menopause and age.
\end{abstract}

Received date: May 23, 2017

Accepted date: August 22, 2017

Published date: August 24, 2017

Citation: Coughlin, S.S., et al. A Review of Epidemiologic Studies of the Health of Gulf War Women Veterans. (2017) J Environ Health Sci 3(2): 54- 62.

DOI: $10.15436 / 2378-6841.17 .1551$

Keywords: Gulf War syndrome; Gulf War veterans; Symptoms; Epidemiology; Women's health

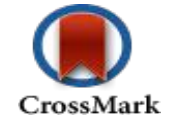




\section{Introduction}

Women comprised almost 7 percent of the nearly 700,000 military personnel who served in the 1991 Gulf War and represented the largest proportion of U.S. women serving in a war zone in U.S. military history to that point in time. In addition, expanded military roles for women increased their exposure to more intense levels of combat and to toxicant exposures (Bond, 2004). Woman GW veterans, therefore, may have health issues specific to their cohort that are more frequent than among other cohorts of women veterans or among non-veteran women. Several studies have examined rates of Gulf War Illness (GWI) and rates of psychiatric illnesses by gender in GW veterans. GWI illness is sometimes referred to as medically unexplained multisymptom illness or chronic multisymptom illness (Wolfe, et al. 2002; Coughlin, et al. 2013).

Some results from (Wolfe, et al. 2002; Coughlin, et al. 2013) but not all (Unwin, et al. 2002) suggest that GWI is more common in women GW veterans than their male counterparts and additional studies have found no gender difference in the prevalence of GWI. A small number of studies suggested excess rates of woman's health problems, e.g., breast cysts, abnormal Papanicolaou (Pap) smears, yeast infections, and bladder infections (Pierce, 1997; Unwin, et al. 2002; Pierce, 2005). However, in the 25 years since the war, few studies have evaluated GWI and other medical and neurological conditions specifically in women GW veterans (Pierce, 1997). In addition to the lack of studies specific to gender, the original research that was conducted was more than 10 years ago and to our knowledge, follow-up studies have not been completed.

In this article, we review published epidemiologic studies on the health of GW women and identify gaps in our current understanding of the health of women who were deployed to the GW or who served elsewhere during that era. We also summarize published studies of adverse reproductive outcomes such as ectopic pregnancies, spontaneous abortions, stillbirths, and birth defects. Finally, we offer several recommendations for further research on the health of women $\mathrm{GW}$ veterans.

\section{Methods}

The present review is based upon bibliographic searches in PubMed and CINAHL and relevant search terms. Articles published in English from 1990 through September 2015 were identified using the following medical subject heading (MeSH) search terms and Boolean algebra commands: (Gulf War) and (veterans health) and ((women's health) or (women)). The searches were not limited to words appearing in the title of an article. Information obtained from bibliographic searches (title and topic of article, information in abstract, and key words) was used to determine whether to retain each article identified in this way. In addition, we reviewed the references of reports prepared by the Institute of Medicine and the Research Advisory Committee on Gulf War Illness Research and published review articles. A total of 56 article citations were identified in the bibliographic searches as detailed in Figure 1. After screening the abstracts or full texts of these articles, and examining the references of review articles and reports, 21 studies were identified for further review. This included one study that focused specifically on women GW veterans (Pierce, 1997; Pierce, 2005); a study of women veterans from more than one era, in which results were reported separately by era (Washington, et al. 2013); 10 studies of both male and female GW veterans in which at least some results were reported separately for women (CDC, 1995; Fukuda, et al. 1998; Steele, 2000; Wolfe, et al. 2002; Kang, et al. 2005; Coughlin, et al. 2013; Smith, et al. 2013; Provenzale D, 2015); and 9 studies of adverse reproductive outcomes and birth defects (Cowan, et al. 1997; Araneta, et al. 2000; Kang, et al. 2001; Araneta, et al. 2003; Araneta, et al. 2004; Doyle, et al. 2004; Wells, et al. 2006; Kelsall, et al. 2007; Verret, et al. 2008). Several studies were also identified of mortality and cancer incidence among male and female GW veterans (Kang, et al. 1996; Macfarlane, et al. 2000; Kang, et al. 2001; Macfarlane, et al. 2003; Macfarlane, et al. 2005; Lincoln, et al. 2007). The present review extends upon the work of earlier authors (Pierce, 1997; Unwin, et al. 2002; Pierce, 2005) by including studies published in the last several years and by offering suggestions for further epidemiologic research on the health of women Gulf War veterans.

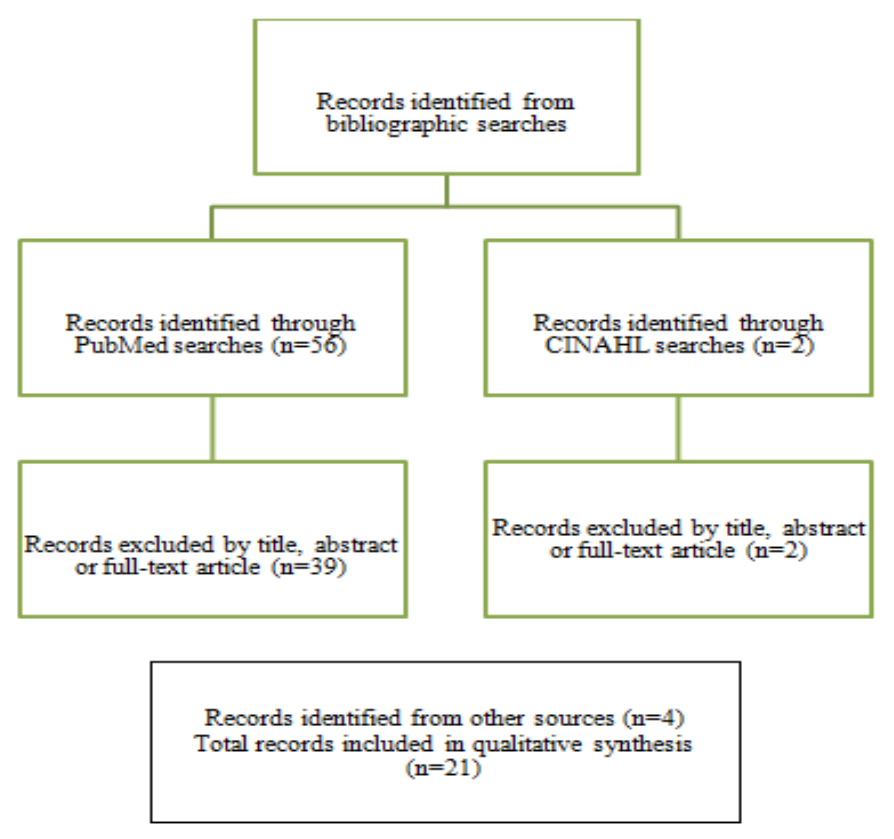

Figure 1: Summary of search and exclusion process.

\section{Results}

Epidemiologic surveys that have examined the health of women GW veterans are summarized in Table 1. Several questions related to women's health have been asked in surveys of the Ft. Devens, Massachusetts cohort including difficulty conceiving, whether a child was born with a birth defect, stillbirths, uterine or ovary tumors, hysterectomy, menopause, amenorrhea, vaginal yeast infections, premenstrual symptoms, pain during intercourse, difficulty achieving orgasm, and breast disease (Wolfe, et al. 2002). About $60 \%$ of the respondents met the Centers for Disease Control and Prevention (CDC) criteria for chronic multisymptom illness (CMI). In addition to female gender, positive associations were found for those with lower levels of education, self-reported use of a medical clinic in the Gulf, ingestion of anti-nerve gas pills, anthrax vaccination, tent heaters, and exposure to oil fire smoke, and chemical odors were related to CMI in logistic regression analyses. 
Epidemiologic Studies of the Health of Women Veterans

Table 1: Design characteristics of studies of U.S. veterans of the first Gulf War that provided information about the health of women veterans.

\begin{tabular}{|c|c|c|c|c|c|}
\hline Study & Inception & Design & Administration & Population eligible to participate & Focus \\
\hline $\begin{array}{l}\text { Devens Cohort } \\
\text { Study (Wolfe } \\
\text { et al. 2002) }\end{array}$ & $\begin{array}{l}1991, \\
1995-1996, \\
1997, \\
2013 \\
\text { (ongoing) }\end{array}$ & $\begin{array}{l}\text { Repeat } \\
\text { cross-sectional } \\
\text { surveys of es- } \\
\text { tablished cohort }\end{array}$ & $\begin{array}{l}\text { Initial re-adjust- } \\
\text { ment survey, } \\
\text { with follow-up } \\
\text { surveys by mail } \\
\text { or in-person }\end{array}$ & $\begin{array}{l}\text { Deployed Army soldiers ( } 84 \text { units, } \mathrm{n}= \\
2,300 \text { ) returning from GW through Ft. } \\
\text { Devens, MA }\end{array}$ & $\begin{array}{l}\text { Physical and psychological } \\
\text { health, symptoms, repro- } \\
\text { ductive history, adverse } \\
\text { birth outcomes, women's } \\
\text { health, domestic and military } \\
\text { exposures }\end{array}$ \\
\hline $\begin{array}{l}\text { Longitudinal } \\
\text { Health Study } \\
\text { (Kang et al. } \\
2000,2009 \text { ) }\end{array}$ & 1993-1995 & $\begin{array}{l}\text { Cross-sectional } \\
\text { survey of } \\
\text { established } \\
\text { cohort with } \\
\text { follow-up } \\
\text { surveys } \\
\text { conducted in } \\
2005 \text { and } 2012\end{array}$ & $\begin{array}{l}\text { Mail survey, } \\
\text { telephone inter- } \\
\text { views; web-based } \\
\text { survey added in } \\
2012\end{array}$ & $\begin{array}{l}\text { National sample of } G W(n=15,000) \\
\text { and } G W \text { era }(n=15,000) \text { veterans }\end{array}$ & $\begin{array}{l}\text { Health status, health care use, } \\
\text { physical and psychological } \\
\text { health conditions, symptoms, } \\
\text { military exposures. Ques- } \\
\text { tions on reproductive health } \\
\text { outcomes were included in } \\
\text { the } 1995 \text { survey. Questions } \\
\text { on women's health were in- } \\
\text { cluded in the } 2012 \text { follow-up } \\
\text { survey }\end{array}$ \\
\hline $\begin{array}{l}\text { USAF (Pierce } \\
1997,2005)\end{array}$ & 1993 & $\begin{array}{l}\text { Cross-sectional } \\
\text { survey and } \\
\text { follow-up } \\
\text { surveys } \\
\text { conducted } 2 \text { and } \\
4 \text { years later }\end{array}$ & Mail surveys & $\begin{array}{l}\text { Sample of } 525 \text { USAF women } \\
\text { (expanded to 2,400 women for the } \\
\text { second follow-up survey) who served } \\
\text { in USAF, stratified on component } \\
\text { (active, National Guard, or reserve), } \\
\text { deployment (in the theater or deployed } \\
\text { elsewhere), and parental status (parent } \\
\text { or nonparent) }\end{array}$ & $\begin{array}{l}\text { Physical and psychological } \\
\text { health, symptoms, gen- } \\
\text { der-specific health }\end{array}$ \\
\hline $\begin{array}{l}\text { Air Nat'l } \\
\text { Guard (Fukuda } \\
\text { et al. 1998; } \\
\text { CDC 1995) }\end{array}$ & 1994 & Cross-sectional & & $\begin{array}{l}\text { GW veterans from a PA-based Air } \\
\text { National Guard unit, two USAF re- } \\
\text { serve units (PA, FL) and an active duty } \\
\text { USAF unit (FL) }(n=3,927)\end{array}$ & $\begin{array}{l}\text { Physical health, symptoms, } \\
\text { risk factors for illness }\end{array}$ \\
\hline $\begin{array}{l}\text { (Unwin et al. } \\
\text { 2002) }\end{array}$ & Post-1997 & $\begin{array}{l}\text { Cross-sectional } \\
\text { survey }\end{array}$ & Mail survey & $\begin{array}{l}\text { Random sample of UK Armed Forces } \\
\text { Personnel. } 4,250 \text { deployed to GW, } \\
4,250 \text { non-deployed, plus Bosnia } \\
\text { cohort. Women }(n=1,026) \text { were over- } \\
\text { sampled }\end{array}$ & $\begin{array}{l}\text { Physical and psychological } \\
\text { symptoms, medical disorders, } \\
\text { military exposures }\end{array}$ \\
\hline $\begin{array}{l}\text { Kansas } \\
\text { (Steele 2000) }\end{array}$ & 1998 & $\begin{array}{l}\text { Cross-sectional } \\
\text { study }\end{array}$ & Telephone survey & $\begin{array}{l}\text { KS veterans or reserve members } \\
(n=2,030) \text { who served on active duty } \\
\text { between } 8 / 90 \text { and } 7 / 91\end{array}$ & $\begin{array}{l}\text { Physical and psychological } \\
\text { health, symptoms, military } \\
\text { exposures }\end{array}$ \\
\hline $\begin{array}{l}\text { Millennium } \\
\text { Cohort Study } \\
\text { (Gray et al. } \\
\text { 2002; Smith et } \\
\text { al. 2014) }\end{array}$ & 2001 & $\begin{array}{l}\text { Repeated } \\
\text { cross-sectional } \\
\text { surveys }\end{array}$ & $\begin{array}{l}\text { Mail survey, } \\
\text { telephone survey }\end{array}$ & $\begin{array}{l}\text { Random sample of US military person- } \\
\text { nel serving in October } 2000 \text { (panel } \\
\text { one). Random sample of military per- } \\
\text { sonnel with } 1 \text { to } 2 \text { years of service as } \\
\text { of October } 2003 \text { (panel two), and more } \\
\text { recent panels. Marines and women } \\
\text { were over sampled in panel two }\end{array}$ & $\begin{array}{l}\text { Health status, health care use, } \\
\text { medical and psychological } \\
\text { health, symptoms, military } \\
\text { exposures }\end{array}$ \\
\hline $\begin{array}{l}\text { Iowa Gulf War } \\
\text { Study (Carney } \\
\text { et al. 2003) }\end{array}$ & $1995-1996$ & $\begin{array}{l}\text { Cross-sectional } \\
\text { study }\end{array}$ & Telephone survey & $\begin{array}{l}\text { Sample of } 4,886 \mathrm{GW} \text { era veterans from } \\
\text { Iowa ( } 9.2 \% \text { women) stratified on GW } \\
\text { deployment and military status, age, } \\
\text { gender, race, officer status, and branch } \\
\text { of service }\end{array}$ & $\begin{array}{l}\text { Health status, health care use, } \\
\text { military preparedness and } \\
\text { exposures }\end{array}$ \\
\hline $\begin{array}{l}\text { National Sur- } \\
\text { vey of Women } \\
\text { Veterans } \\
\text { (Washington et } \\
\text { al. 2013) }\end{array}$ & 2009 & $\begin{array}{l}\text { Cross-sectional } \\
\text { survey of ran- } \\
\text { dom sample of } \\
\text { women veterans }\end{array}$ & Telephone survey & $\begin{array}{l}\text { National sample of 3,611 women } \\
\text { veterans }\end{array}$ & $\begin{array}{l}\text { Healthcare delivery pref- } \\
\text { erences, health care use, } \\
\text { general health status, physical } \\
\text { and psychological health } \\
\text { conditions }\end{array}$ \\
\hline $\begin{array}{l}\text { Survey of GW } \\
\text { veterans (Vogt } \\
\text { et al. } 2007 \text {, } \\
2008 \text {; } \\
\text { Smith et al. } \\
2013 \text { ) }\end{array}$ & Not stated & $\begin{array}{l}\text { Cross sectional } \\
\text { survey }\end{array}$ & mail survey & $\begin{array}{l}\text { National sample of } 495 \mathrm{GW} \text { veterans } \\
(25 \% \text { women) from all branches of } \\
\text { service and unit components }\end{array}$ & $\begin{array}{l}\text { Combat experiences, per- } \\
\text { ceived threat, difficult living } \\
\text { and working environment, } \\
\text { concerns about family/rela- } \\
\text { tionship disruptions, sexual } \\
\text { harassment, psychological } \\
\text { health conditions, physical } \\
\text { symptoms }\end{array}$ \\
\hline
\end{tabular}


Epidemiologic Studies of the Health of Women Veterans

Table 2: Participant characteristics and findings of studies of U.S. veterans of the first Gulf War that provided information about the health of women veterans.

\begin{tabular}{|c|c|c|c|c|c|}
\hline Study & $\begin{array}{l}\text { Number of GW } \\
\text { women who } \\
\text { participated }\end{array}$ & $\begin{array}{l}\text { Number of } \\
\text { GW men who } \\
\text { participated }\end{array}$ & $\begin{array}{l}\text { Comparison } \\
\text { group }\end{array}$ & Findings & Other Information \\
\hline $\begin{array}{l}\text { Devens Cohort Study } \\
\text { (Wolfe et al. 2002) }\end{array}$ & $\begin{array}{l}\text { Of } 1,290 \text { participants } \\
\text { in the } 1997 \text { survey, } \\
10.4 \% \text { were women } \\
\text { GW veterans }\end{array}$ & $\begin{array}{l}\text { In } 1997,90.6 \% \\
\text { of } 1,290 \\
\text { respondents } \\
\text { were men }\end{array}$ & N/A & $\begin{array}{l}\text { Female gender, lower levels of } \\
\text { education, self-reported use of a } \\
\text { medical clinic in the Gulf, inges- } \\
\text { tion of anti-nerve gas pills, anthrax } \\
\text { vaccination, tent heaters, and expo- } \\
\text { sure to oil fire smoke, and chem- } \\
\text { ical odors were related to MSI in } \\
\text { logistic regression analyses. }\end{array}$ & $\begin{array}{l}\text { Additional analyses } \\
\text { of data for women } \\
\text { are planned. }\end{array}$ \\
\hline $\begin{array}{l}\text { National Health } \\
\text { Study/ Longitudinal } \\
\text { Health Study (Kang } \\
\text { et al. 2000, 2005, } \\
\text { 2009) }\end{array}$ & $\begin{array}{l}11,441 \mathrm{GW} \text { veterans, } \\
19.7 \% \text { women }\end{array}$ & $\begin{array}{l}\text { 9,476 non-de- } \\
\text { ployed GW era } \\
\text { veterans }\end{array}$ & & $\begin{array}{l}\text { Among GW veterans, the adjusted } \\
\text { odds ratio for PTSD associated } \\
\text { with a report of sexual assault was } \\
5.41(95 \% \text { confidence interval [CI] } \\
3.19-9.17) \text { in female veterans and } \\
6.21(95 \% \text { CI } 2.26-17.04) \text { in male } \\
\text { veterans (19). }\end{array}$ & \\
\hline $\begin{array}{l}\text { USAF (Pierce 1997, } \\
\text { 2005) }\end{array}$ & 160 to 625 & $\mathrm{~N} / \mathrm{A}$ & $\begin{array}{l}365 \text { to } 539 \mathrm{GW} \\
\text { era women } \\
\text { deployed else- } \\
\text { where }\end{array}$ & & $\begin{array}{l}\text { Women deployed } \\
\text { to the Gulf reported } \\
\text { increased general } \\
\text { health problems, } \\
\text { skin rash, cough, } \\
\text { depression, uninten- } \\
\text { tional weight loss, } \\
\text { insomnia, memory } \\
\text { problems, breast } \\
\text { lumps or cysts, } \\
\text { and abnormal Pap } \\
\text { teststhan did women } \\
\text { deployed elsewhere } \\
(\mathrm{p}<0.05) \text {. }\end{array}$ \\
\hline $\begin{array}{l}\text { Air Nat'l Guard } \\
\text { (Fukuda et al. 1998; } \\
\text { CDC 1995) }\end{array}$ & $\begin{array}{l}\text { Of } 3,723 \text { partici- } \\
\text { pants, } 14 \% \text { were } \\
\text { female, } 47 \% \text { were } \\
\text { deployed to the } \\
\text { Persian Gulf. The } \\
\text { number of deployed } \\
\text { women was not } \\
\text { reported }\end{array}$ & $\begin{array}{l}\text { About } 86 \% \\
\text { were male, } \\
47 \% \text { were } \\
\text { deployed; } \\
\text { the number } \\
\text { of deployed } \\
\text { men was not } \\
\text { reported }\end{array}$ & $\begin{array}{l}\text { Air Nat'l } \\
\text { Guard not } \\
\text { deployed to the } \\
\text { Persian Gulf }\end{array}$ & & $\begin{array}{l}\text { Additional analyses } \\
\text { of data for women } \\
\text { are planned. }\end{array}$ \\
\hline (Unwin et al. 2002) & $226 \mathrm{GW}$ women & & $\begin{array}{l}192 \text { non-de- } \\
\text { ployed GW era } \\
\text { women, and } \\
227 \text { deployed } \\
\text { to Bosnia }\end{array}$ & $\begin{array}{l}\text { Women were significantly more } \\
\text { likely than men to report } 6 \text { symp- } \\
\text { toms (headaches, fatigue, constipa- } \\
\text { tion, stomach cramp, passing urine } \\
\text { more often, and nausea). Women } \\
\text { deployed to the Persian Gulf had } \\
\text { similar rates of ill health as their } \\
\text { male counterparts. GW women } \\
\text { veterans were about three times } \\
\text { as likely to meet the CDC criteria } \\
\text { for CMI than GW era women vet- } \\
\text { erans, and as compared to women } \\
\text { who were deployed to Bosnia. }\end{array}$ & \\
\hline Kansas (Steele 2000) & 216 & 1,331 & $\begin{array}{l}482 \text { non-de- } \\
\text { ployed GW } \\
\text { era veterans } \\
\text { residing in KS }\end{array}$ & & $\begin{array}{l}\text { Questions about } \\
\text { women's health (e.g., } \\
\text { questions to assess } \\
\text { menopausal status) } \\
\text { were included in the } \\
\text { survey questionnaire. }\end{array}$ \\
\hline
\end{tabular}


Epidemiologic Studies of the Health of Women Veterans

\begin{tabular}{|c|c|c|c|c|}
\hline $\begin{array}{l}\text { Millennium Cohort } \\
\text { Study (Smith et al. } \\
\text { 2014) }\end{array}$ & $\begin{array}{l}\mathrm{n}=73,078,74.0 \% \text { de- } \\
\text { ployed to the Persian } \\
\text { Gulf, } 21.6-33.4 \% \\
\text { women }\end{array}$ & $\begin{array}{l}\mathrm{n}=73,078, \\
74.0 \% \text { de- } \\
\text { ployed to the } \\
\text { Persian Gulf, } \\
66.6-78.4 \% \\
\text { men }\end{array}$ & & $\begin{array}{l}\text { A higher prevalence of CMI was } \\
\text { observed among GW veterans as } \\
\text { compared with non-deployed vet- } \\
\text { erans who had served during that } \\
\text { same era. Women had a higher } \\
\text { prevalence of CMI over time than } \\
\text { men }\end{array}$ \\
\hline $\begin{array}{l}\text { Iowa Gulf War Study } \\
\text { (Carney et al. 2003) }\end{array}$ & $129 \mathrm{GW}$ women & $3,695 \mathrm{GW}$ men & $\begin{array}{l}206 \text { non-de- } \\
\text { ployed GW era } \\
\text { women }\end{array}$ & $\begin{array}{l}\text { Men and women had similar } \\
\text { military experiences but men more } \\
\text { often participated in combat. Men } \\
\text { were more likely than women } \\
\text { to report exposures to smoke, } \\
\text { psychological stress, and lead. No } \\
\text { significant gender differences were } \\
\text { found in exposure to solvents/ pet- } \\
\text { rochemicals, infectious diseases, } \\
\text { neurotoxins, heat stress, trauma, } \\
\text { or radiation. Compared with male } \\
\text { GW veterans, GW women veterans } \\
\text { had more outpatient and inpa- } \\
\text { tient health care use } 5 \text { years after } \\
\text { deployment. }\end{array}$ \\
\hline $\begin{array}{l}\text { National Survey of } \\
\text { Women Veterans } \\
\text { (Washington et al. } \\
\text { 2013) }\end{array}$ & $\begin{array}{l}780 \mathrm{GW} \text { era women } \\
\text { veterans, deployment } \\
\text { status not reported }\end{array}$ & N/A & $\begin{array}{l}\text { WW II, Korea } \\
\text { era, Vietnam } \\
\text { era, and OEF/ } \\
\text { OIF/ OND } \\
\text { era women } \\
\text { veterans }\end{array}$ & $\begin{array}{l}\text { GW era women veterans }(n=780) \\
\text { often cited cost of care as an im- } \\
\text { portant consideration. }\end{array}$ \\
\hline $\begin{array}{l}\text { Survey of GW } \\
\text { veterans (Vogt et al. } \\
\text { 2007, 2008; Smith et } \\
\text { al. 2013) }\end{array}$ & $83 \mathrm{GW}$ women & $234 \mathrm{GW}$ men & & $\begin{array}{l}\text { Several gender differences in } \\
\text { exposure were observed along } \\
\text { with gender-related differences in } \\
\text { associations between deployment } \\
\text { stressors and mental health out- } \\
\text { comes. Among men and women } \\
\text { combined, } 33.8 \% \text { met CDC criteria } \\
\text { for CMI. }\end{array}$ \\
\hline
\end{tabular}

The National Health Survey/Longitudinal Health Study of Gulf War Era Veterans (Kang, et al. 2000; Kang, et al. 2009) is one of the largest studies of the health of male and female $\mathrm{GW}$ and $\mathrm{GW}$ era veterans. A sample of 30,000 veterans $(50 \%$ deployed to the Persian Gulf, $20 \%$ women) were initially invited to participate in1995 and again in 2005 and 2012. Branch of service (Army, Navy, Air Force, and Marine Corps) and unit component (active, reserve, National Guard) were represented in both groups. A stratified random sampling method was employed to ensure that women and those who served in the reserve or National Guard were adequately represented. Although this study has provided a wealth of information about the health of GW veterans and non-deployed GW era veterans, most published analyses have controlled for gender rather than reporting gender-specific results. A notable exception is an article by Kang et al. 2005, on the role of sexual assault on the risk of PTSD among GW veterans. The adjusted odds ratio for PTSD associated with a report of sexual assault was 5.41 (95\% confidence interval [CI] 3.19 - 9.17) in female veterans and 6.21 (95\% CI 2.26 - 17.04) in male veterans (Kang, et al. 2005). Neither the CDC criteria for CMI nor the Kansas criteria for GWI have been used in published analyses of data from this study (Coughlin, et al. 2013). Results from the 2012 follow-up survey, which included questions about women's health, were recently reported.

Pierce, 1997, studied a stratified representative sample of GW and GW era military service women who served in the
USAF. The control group consisted of GW era women veterans who were deployed elsewhere. The study included a stratified sample of women who were interviewed about two years following the war and again in a follow-up study conducted two years later (Pierce, 1997). The sampling frame was stratified on component of the U.S. Air Force (USAF) (active, National Guard, or reserve), deployment (in the Persian Gulf theater or elsewhere), and parental status (parent or nonparent). Certain strata were over-sampled so that the sample consisted of $50 \%$ active duty, $25 \%$ reserve, and $25 \%$ guard, and $33 \%$ deployed to the theater of operations vs. $66 \%$ who served elsewhere during the same period of time. Of the 638 who were sampled, 525 $(82 \%)$ women were located and, of those, 509 (97\%) participated. Subsequent data collection included self-administered postal surveys that had response rates of $92 \%(n=484)$ and $87 \%(n=$ 456), respectively (Pierce, 1997). Measures included items concerning general physical health and gender-specific health items. In addition to questions about general health status, survey items were included of 18 symptoms of gender-specific health problems and 17 medications for which medical treatment or health services were sought. Multiple statistical analyses were used to describe women's physical and emotional health at two time points following the war. Women deployed to the theater reported significantly more general health problems as well as gender-specific health problems than did women deployed elsewhere $(p<0.05)$. A cluster of common health problems includ- 
ed: skin rash, cough, depression, unintentional weight loss, insomnia, and memory problems (Pierce, 2005). Women serving in the theater also reported a significant increase in gender-specific problems (i.e., lumps or cysts in the breasts, abnormal Pap tests) compared to women deployed elsewhere. In a further follow-up survey of this cohort of USAF women two years later, a total sample of 2,400 women were sampled (1,200 GW and 1,200 deployed elsewhere during the GW era) and 1,164 completed the survey (Pierce, 2005). About $45 \%$ of the initial sample responded. Women deployed to the theatre continued to report more health problems compared with women deployed elsewhere during the same period, after adjustment for age, education, smoking, and alcohol use $(\mathrm{p}<0.001)$. An association with GW deployment was observed for 29 of 48 symptoms (Pierce, 2005).

In November 1994, the VA, DoD, and the Pennsylvania Department of Health requested that the CDC investigate a report of unexplained illnesses among members of an Air National Guard unit who were GW veterans. After an initial investigation of $59 \mathrm{GW}$ veterans, which involved standardized interviews and physical examinations, a larger sample of GW veterans (n $=3,927$ ) were surveyed in 1995, who were members of the index unit and three comparison units in Pennsylvania and Florida (CDC, 1995; Fukuda, et al. 1998). After excluding 204 who were younger than 17 years during the $\mathrm{GW}, 1,163$ (31.2\%) were GW veterans and 2,560 (68.8\%) had not been deployed (Fukuda, et al. 1998). In addition to general health history, the respondents were asked about the frequency, duration, and severity of 35 symptoms and possible exposures during deployment. In all units, the prevalence of each of 13 chronic symptoms was significantly greater $(\mathrm{p}<0.05)$ among persons deployed to the GW than among those not deployed. The prevalence of mild-to-moderate and severe cases of CMI was $39 \%$ and $6 \%$, respectively, among male and female GW veterans compared with $14 \%$ and $0.7 \%$ among 2,520 non-deployed veterans. Although no physical examination, laboratory, or serologic findings identified cases, veterans who met the case definition had significantly diminished functioning and well-being (Fukuda, et al. 1998). About $14 \%$ of the participants in the CDC study are women.

Unwin et al. 2002, conducted a cross-sectional mailed survey of a random sample of United Kingdom Armed Forces Personnel who were deployed to the GW, non-deployed controls and controls who were deployed to Bosnia. The GW cohort consisted of 4,000 deployed veterans plus an additional 250 women who were oversampled. The total sample size for the deployed cohort was 4,250 and the same number for the non-deployed cohort. The stratification variables were service (Royal Navy, Army, Royal Air Force), gender, age, service status (regular or reservist), rank (officer or other), and fitness (Army and Royal Air Force only). The questionnaire was completed by 645 women, 226 from the GW cohort, 227 from the Bosnia cohort, and 192 from the GW era cohort. The health of service women was compared with that of service men. The main outcome measures were physical symptoms and illnesses, functional capacity, and $\mathrm{CMI}$ defined using the CDC criteria. No gender differences were found for 32 of the 50 symptoms. Women were significantly more likely than men to report 6 symptoms (headaches, fatigue, constipation, stomach cramp, passing urine more often, and nausea). GW women had similar rates of ill health as their male counterparts (Unwin et al. 2002). GW women veterans were about three times as likely to meet the CDC criteria for CMI as non-deployed GW era women veterans, and as compared to women who were deployed to Bosnia (Unwin et al. 2002).

In a study conducted in Kansas in 1998, Steele, (2000); used telephone interviews of 1,548 veterans who served in the GW and 482 who served elsewhere during the GW era. All of the subjects lived in Kansas at the time of the study. In addition to general questions about military service, the respondents were asked about the severity of 37 symptoms in the past year and when the symptoms first occurred. They were also asked if they had ever been diagnosed or treated by a physician for any of 16 medical and psychiatric conditions, or for any medical condition in 5 general areas, and when each reported condition had developed. GWI, defined as having chronic symptoms in 3 of 6 domains, occurred in $34 \%$ of GW veterans, $12 \%$ of non-deployed GW era veterans who reported receiving vaccines during the war, and $4 \%$ of non-deployed GW era veterans who did not receive vaccines (Steele, 2000). The prevalence of GWI was lowest among GW veterans who served on board ship (21\%) and highest among those who were in Iraq and/or Kuwait (42\%). Questions about women's health (e.g., questions to assess menopausal status) were included in the survey questionnaire. About $15.9 \%$ of the participants in the Kansas study are women. Additional analyses of data for women, and to compare female-tomale differences in risk of GWI and frequency of symptoms, are planned.

The Millennium Cohort Study (Gray, et al. 2002; Smith, et al. 2014) is one of the largest, ongoing studies of US military personnel and veterans. The study was launched in 2001 to examine deployment, demographic, behavioral, and occupational characteristics related to military service and various health outcomes. The first panel of participants invited to participate in the study was randomly selected from US military personnel who were serving in October 2000. Persons who had been deployed to Bosnia, Southwest Asia, or Kosovo between 1998 and 2000, Reserve and National Guard members, and women were oversampled. The second panel of invited participants was randomly selected from military personnel with 1 to 2 years of service as of October 2003. Marines and women were oversampled in the second panel. In an analysis of data from panels one and two $(\mathrm{n}=73,078,74.0 \%$ deployed to the Persian Gulf, 21.6$33.4 \%$ women), Smith et al. 2014, examined 18 symptoms that have been reported to be higher among GW veterans (severe headache; diarrhea; rash or skin ulcer; sore throat; night sweats; chest pain; unusual muscle pains; shortness of breath; trouble sleeping; unusual fatigue; sudden unexplained hair loss; being sleepy all the time; forgetfulness; stomach pain; pain in the arms, legs, or joints; cough; feeling down, depressed, or hopeless; and feeling nervous, anxious, or on edge or worrying about different things). The CDC criteria were used to assess CMI. A higher prevalence of CMI was observed among GW veterans as compared with non-deployed veterans who had served during that same era. Women had a higher prevalence of CMI over time than men (Smith, et al. 2014).

In a random sample of GW veterans from Iowa, Carney et al. 2003 compared the combat experiences, occupational and other service-related exposures, and health care use of GW male and female veterans. The sample $(n=4,886$ potential subjects, $9.2 \%$ women) was stratified by GW deployment and military status (active duty, National Guard/reserve), age, gender, race, 
officer status, and branch of service. Deployed women $(n=129)$ were more often in the Army, single, without children, college educated, and reported fewer vaccinations than deployed men (n $=3,695$ ). Men and women had similar military experiences but men more often participated in combat. Women were less likely than men to report exposures to smoke, psychological stress, and lead. No significant gender differences were found in exposure to solvents/petrochemicals, infectious diseases, neurotoxins, heat stress, trauma, or radiation (Carney, et al. 2003). Compared with male GW veterans, GW women veterans had more outpatient and inpatient health care use 5 years after deployment.

The National Survey of Women Veterans (Washington, et al. 2013) is a nationally representative sample of 3,611 women veterans surveyed by telephone in 2009 . Women who served during different eras (World War II, Korea, Vietnam, first GW, and Operations Enduring Freedom, Iraqi Freedom, New Dawn) are represented. Washington et al. 2013, examined the healthcare delivery preferences and use (types of healthcare services and number of visits used, use of VA or non-VA healthcare services) of women veterans by military service era. GW era women veterans $(n=780)$ often cited cost of care as an important consideration.

Vogt et al. (2007; 2008) studied $495 \mathrm{GW}$ veterans from across the U.S. Women were oversampled at $25 \%$. Participants ( $\mathrm{n}=317,26.2 \%$ women) deployed from active duty, reserve, and National Guard units and represented the Army, Navy, Air Force, Marines, and Coast Guard branches of the military. Several gender differences in exposure were observed along with gender-related differences in associations between deployment stressors and mental health outcomes. For example, as concerns about family/relationship disruptions increased, levels of anxiety increased for both women and men; however, the strength of the association was stronger for women than men. Using data from this same study, Smith et al. 2013 found that $33.8 \%$ met CDC criteria for CMI. The prevalence of CMI was not reported for men and women separately.

Several epidemiologic studies have examined reproductive outcomes among GW veterans (Cowan, et al. 1997; Araneta, et al. 2000; Kang, et al. 2001; Araneta, et al. 2003; Araneta, et al. 2004; Doyle, et al. 2004; Wells, et al. 2006; Kelsall, et al. 2007; Verret, et al. 2008). Several studies have identified significantly elevated rates of birth defects and adverse reproductive outcomes among GW veterans. This includes findings reported in 2001 from VA's large national survey of U.S. Gulf War veterans indicating that children born to women GW veterans had nearly three times the rate of "likely" birth defects as children of women veterans of the same period who did not serve in the Gulf War (Kang, et al. 2001). In the National Health Survey (n $=15,000 \mathrm{GW}$ Veterans and $\mathrm{n}=15,000$ non-deployed $\mathrm{GW}$ era Veterans; 20\% women), Kang et al. 2001, found that male GW veterans, compared with their non-Gulf Veteran controls, reported a significantly higher rate of miscarriage (odds ratio [OR] = $1.62 ; 95 \%$ confidence interval $[\mathrm{CI}]=1.32-1.99$ ). Female GW veterans also reported more miscarriages than their respective controls, although their excess was not statistically significant $(\mathrm{OR}=1.35 ; \mathrm{CI}=0.97-1.89)$. Both men and women deployed to the Gulf Theater of operations reported significant excesses of birth defects among their live born infants. These excess rates also extended to the subset of "moderate to severe" birth defects [males: $\mathrm{OR}=1.78(\mathrm{CI}=1.19-2.66)$; females: $\mathrm{OR}=2.80(\mathrm{CI}=$
1.26-6.25)]. No statistically significant differences by deployment status were found among men or women for stillbirths, preterm deliveries or infant mortality (Kang, et al. 2001). Overall, however, findings have varied with different study designs and sample sizes, with some studies showing elevated risks of stillbirths, miscarriages, and/or birth defects (Kang, et al. 2001; Araneta, et al. 2003; Araneta, et al. 2004). Increased risks of ectopic pregnancies and spontaneous abortions have been observed in some studies (Araneta, et al. 2000; Araneta, et al. 2004).

\section{Discussion}

The results of this review indicate that there is currently a paucity of epidemiologic studies that have evaluated GWI and other high interest health outcomes in women veteran subgroups, e.g., subgroups identified by deployment characteristics (e.g. location, exposures, and branch of service). Studies often show differences, however, there are limitations in the research that need addressing, including limited numbers of women and variability in job and deployment times. Some, but not all studies adjusted for mental health conditions such as post-traumatic stress disorder when looking at physical health conditions. There may also have been residual confounding or unmeasured confounders in studies that compared male and female Gulf War veterans or in studies that compared Gulf War women veterans and controls. There is a need for additional studies of women veterans who served in the 1990-1991 Gulf War and comparison groups of women who served in other locations during that same time period. This should include extended analyses of existing datasets and new data collection. Much more is known now about the complex configuration of symptoms reported at the time of the 1990-1991 Gulf War. Current, comprehensive data are needed on the health status of women who served during the 1990-1991 Gulf War, and appropriate controls, in order to identify specific conditions that affect GW women veterans at excess rates. Some medical conditions (e.g., rheumatoid arthritis, chronic fatigue syndrome, migraine headache) are known to be more common among women than men, both among veteran and non-veteran populations. Among the questions of interest are: what is the prevalence of GWI among women GW veterans, defined by both the CDC and Kansas criteria (Fukuda, et al. 1998; Steele, 2000). What is the frequency and patterns of veteran-reported chronic symptoms and medical conditions diagnosed by healthcare providers? What is the prevalence of female-specific health symptoms and medical conditions? What are their general health and functional status and use of healthcare services including hospitalizations? Studies are needed to examine sex-differences in GWI including female-to-male differences in the frequency of symptoms that are associated with GWI and the overall-all prevalence of GWI among GW female and male veterans. In particular, longitudinal studies are needed to help separate out exposure outcomes from "normal" aging processes that occur over time. There is a need for longitudinal assessments of changes in GW era women veterans' health over time, using baseline data collected in the original population studies from which current cohort samples are drawn. Studies are also needed to provide comprehensive data on veteran-reported pregnancy and birth outcomes among GW and GW era women veterans.

Few epidemiologic studies that have evaluated GWI 
and other high interest health outcomes in women veteran subgroups, by subgroups identified by age and menopausal status (e.g., pre-, peri- and post-menopause subgroups).Theories about the pathobiology of GWI focus on neuro-immune mechanisms and those mechanisms may be altered by menopause. Menopause has effects on a number of organ systems including the cardiovascular, skeletal, central nervous and genitourinary systems (Gameiro, et al. 2010; Sammaritano, 2012). Studies have shown that following menopause, women can experience an increase in pro-inflammatory serum markers such as IL-1, IL-6, and TNF-alpha (Gameiro, et al. 2010). Given that many women veterans who were deployed to the Gulf region may be in the midst of natural or surgically induced menopause, more research on this topic is important.

There remains a need to evaluate birth outcomes in appropriate subgroups, e.g., by time period of birth, by parental exposures and by other deployment characteristics (e.g., whether the women were later deployed to Operation Enduring Freedom or Operation Iraqi Freedom). There is a paucity of subgroup analyses assessing rates of birth defects and other reproductive outcomes by time period of birth and by parental exposures and other deployment characteristics. Although data from a large GW birth defect registry suggests there may have been significant increases in rates of some birth defects in the early years after the war, but that those differences leveled off over time, GW birth defect studies have not compared rates in GW vs. non deployed GW era veterans by birth year/time period, or by whether the parent veteran had GWI or experienced exposures that may be associated with birth outcomes. Higher diagnosis of birth defects and adverse reproductive outcomes in Gulf War women veterans compared to controls might be in part due to higher awareness, concerns about health issues related to the Gulf War, better access to health care and differential quality of care that veterans receive. Further research is needed to address these important issues.

In summary, further research is needed to provide a comprehensive picture of the health of women GW veterans and to examine a broad range of women's health issues including adverse reproductive outcomes (spontaneous abortions, still births, ectopic pregnancies, pre-term births, and birth defects). This includes assessments of current health status, changes in health symptoms and conditions over time, and possible differences in health outcomes associated with specific experiences and exposures during the war. Future studies would be strengthened by assessing GWI symptom patterns that may be specific to women veterans, examine diagnosed medical conditions among women veterans, and evaluate changes in women's health over time, including changes potentially associated with menopause and age. Such data would improve our understanding of GWI in women veterans who served in the Gulf War, women GW veteran's health, and adverse reproductive outcomes, and lay the groundwork for future research aimed at a short-term or longer-term improvement in clinical treatment of women veterans with GWI, and the definition and diagnosis of GWI in women.

Acknowledgements: The views expressed are those of the authors and do not necessarily reflect the official policy or position of the Air Force, the Department of Defense, or the U.S. Government. This work was supported by the Office of the Assistant Secretary of Defense for Health Affairs, through the
Gulf War Illness Research Program under Award No. W81XWH-16-1-0774.

\section{Reference}

1. Araneta, M.R., Destiche, D.A., Schlangen, K.M., et al. Birth defects prevalence among infants of Persian Gulf War veterans born in Hawaii, 1989-1993. (2000) Teratology 62(4): 195-204.

PubMed | CrossRef | Others

2. Araneta, M.R., Schlangen, K.M., Edmonds, L.D., et al. Prevalence of birth defects among infants of Gulf War veterans in Arkansas, Arizona, California, Georgia, Hawaii, and Iowa, 1989-1993. (2003) Birth Defects Res A Clin Mol Teratol 67(4): 246-260.

PubMed | CrossRef $\mid$ Others

3. Araneta, M.R., Kamens, D.R., Zau, A.C., et al. Conception and pregnancy during the Persian Gulf War: the risk to women veterans. (2004) Ann Epidemiol 14: 109-116.

PubMed | CrossRef $\mid$ Others

4. Bond, E.F. Women's physical and mental health sequellae of wartime service. (2004) Nurs Clin N Am 39(1): 53-68.

PubMed $\mid$ CrossRef $\mid$ Others

5. Carney, C.P., Sampson, T.R., Voelker, M., et al. Women in the Gulf War: combat experience, exposures, and subsequent health care use. (2003) Mil Med 168(8): 654-661.

PubMed | CrossRef| Others

6. CDC. Unexplained illness among Persian Gulf war veterans in an Air National Guard Unit: preliminary report-August 1990-March 1995. (1995) MMWR 44(23): 433-437.

PubMed | CrossRef| Others

7. Coughlin, S.S., McNeil, R.B., Provenzale, D.T., et al. Method issues in epidemiological studies of medically unexplained symptom-based conditions in veterans. (2013) J Mil Veterans Health 21(2): 4-10.

PubMed | CrossRef $\mid$ Others

8. Cowan, D.N., DeFraites, R.F., Gray, G.S., et al. The risk of birth defects among children of Persian Gulf War veterans. (1997) New Engl J Med 336(23): 1650-1656.

PubMed | CrossRef | Others

9. Doyle, P., Maconochie, N., Davies, G., et al. Miscarriage, stillbirth and congenital malformation in the offspring of UK veterans of the first Gulf War. (2004) Int J Epidemiol 33(1): 74-86.

PubMed | CrossRef | Others

10. Fukuda, K., Nisenbaum, R., Stewart, G., et al. Chronic multisymptom illness affecting Air Force veterans of the Gulf War. (1998) JAMA 280(11): 981-988.

PubMed | CrossRef $\mid$ Others

11. Gameiro, C.M., Romao, F., Castelo-Branco, C. Menopause and aging: changes in the immune system —a review. (2010) Maturitas 67(4): 316-320.

PubMed | CrossRef $\mid$ Others

12. Gray, G.C., Chesbrough, K.B., Ryan, M.A., et al. The Millennium Cohort Study: a 21-year prospective cohort study of 140,000 military personnel. (2002) Mil Med 167(6): 483-488.

PubMed | CrossRef $\mid$ Others

13. Kang, H., Mahan, C.M., Lee, K.Y., et al. Illnesses among United States veterans of the Gulf War: a population-based survey of 30,000 veterans. (2000) J Occup Environ Med 42(5): 491-501.

PubMed | CrossRef | Others

14. Kang, H., Li, B., Mahan, C.M., et al. Health of US veterans of 1991 Gulf War: a follow-up survey in 10 years. (2009) J Occup Environ Med 51(4): 401-410.

PubMed | CrossRef $\mid$ Others

15. Kang, H., Dalager, N., Mahan, C., et al. The role of sexual assault on the risk of PTSD among Gulf War veterans. (2005) Ann Epidemiol 15: 191-195.

PubMed | CrossRef | Others 
16. Kang, H., Magee, C., Mahan, C., et al. Pregnancy outcomes among U.S. Gulf War veterans: a population-based survey of 30,000 veterans. (2001) Ann Epidemiol 11(7): 504-511.

PubMed | CrossRef | Others

17. Kang, H.K., Bullman, T.A. Mortality among U.S. veterans of the Persian Gulf war. (1996) New Engl J Med 335(20): 1498-1504.

PubMed | CrossRef |Others

18. Kang, H.K., Bullman, T.A. Mortality among US veterans of the Persian Gulf War: 7-year follow-up. (2001) Am J Epidemiol 154(5): 399-405.

PubMed | CrossRef |Others

19. Kelsall, H.L., Sim, M.R., Ikin, J.F., et al. Reproductive health of male Australian veterans of the 1991 Gulf War. (2007) BMC Public Health 7: 79.

PubMed | CrossRef | Others

20. Lincoln, A.E., Hooper, T.I., Kang, H.K., et al. Motor vehicle fatalities among Gulf War era veterans: charcteristics, mechanisms, and circumstances. (2007) Traffic Inj Prev 7(1): 31-37.

PubMed | CrossRef $\mid$ Others

21. Macfarlane, G.J., Thomas, E., Cherry, N. Mortality amongst United Kingdom Gulf War veterans. (2000) Lancet 356(9223): 17-21.

PubMed | CrossRef | Others

22. Macfarlane, G.J., Hotopf, M., Maconochie, N., et al. Long-term mortality amongst Gulf War veterans: is there a relationship with experiences during deployment and subsequent morbidity? (2005) Int J Epidemiol 34(6): 1403-1408

PubMed | CrossRef|Others

23. Macfarlane, G.J., Biggs, A-M., Maconochie, N., et al. Incidence of cancer among UK Gulf War veterans: cohort study. (2003) BMJ 327: 1373.

PubMed | CrossRef|Others

24. Pierce, P.F. Physical and emotional health of Gulf War veteran women. (1997) Aviat Space Environ Med 68(4): 317-321.

PubMed | CrossRef| Others

25. Pierce, P.F. Monitoring the health of Persian Gulf War veteran women. (2005) Mil Med 170: 349-354.

PubMed | CrossRef $\mid$ Others

26. Provenzale, D. CSP \#585 Gulf War Era Cohort and Biorepository. Project update. Meeting of the Research Advisory Committee on Gulf War Veterans' Illnesses. (2015) Washington, DC.

PubMed |CrossRef|Others

27. Sammaritano, L.R. Menopause in patients with autoimmune diseases. (2012) Autoimmune Rev 11(6-7): A430-A436.

PubMed | CrossRef | Others

28. Smith, T.C., Powell, T.M., Jacobson, I.G., et al. Chronic multisymptom illness: a comparison of Iraq and Afghanistan deployers with veterans of the 1991 Gulf War. (2014) Am J Epidemiol 180(12): 11761187.

PubMed | CrossRef | Others
29. Smith, B.N., Wang, J.M., Vogt, D., et al. Gulf War Illness. Symptomatology among veterans 10 years after deployment. (2013) J Occup Environ Med 55(1): 104-110.

PubMed | CrossRef | Others

30. Smith, B.N., Wang, J.M., Vogt, D., et al. Gulf War Illness. Symptomatology among veterans 10 years after deployment. (2013) J Occup Environ Med 55(1): 104-110.

PubMed |CrossRef|Others

31. Steele, L. Prevalence and patterns of Gulf War illness in Kansas veterans: association of symptoms with characteristics of person, place, and time of military service. (2000) Am J Epidemiol 152(10): 992-1002. PubMed | CrossRef | Others

32. Unwin, C., Hotopf, M., Hull, L., et al. Women in the Persian Gulf: lack of gender differences in long-term health effects of service in United Kingdom Armed Forces in the 1991 Persian Gulf War. (2002) Mil Med 167: 406-413.

PubMed | CrossRef $\mid$ Others

33. Verret, C., Jutand, M.A., De Vigan, C., et al. Reproductive health and pregnancy outcomes among French gulf war veterans. (2008) BMC Public Health 8:141

PubMed |CrossRef|Others

34. Vogt, D.S., Pless, A.P., King, L.A., et al. Deployment stressors, gender, and mental health outcomes among Gulf War I veterans. (2007) J Trauma Stress 18(3): 272-384.

PubMed |CrossRef | Others

35. Vogt, D.S., Samper, R.E., King, D.W., et al. Deployment stressors and posttraumatic stress symptomatology: comparing active duty and National Guard/reserve personnel from Gulf War I. (2008) J Trauma Stress 21(1): 66-74.

PubMed | CrossRef | Others

36. Washington, D.L., Bean-Mayberry, B., Hamilton, A.B., et al. Women veterans' healthcare delivery preferences and use by military service era: findings from the National Survey of Women Veterans. (2013) J Gen Intern Med 28(Suppl 2): S571-S576.

PubMed |CrossRef|Others

37. Wells, T.S., Wang, L.Z., Spooner, C.N., et al. Self-reported reproductive outcomes among male and female 1991 Gulf War era US military veterans. (2006) Matern Child Health J 10: 501-510.

PubMed | CrossRef $\mid$ Others

38. Wolfe, J., Proctor, S.P., Erickson, D.J., et al. Risk factors for multisymptom illness in US Army veterans of the Gulf War. (2002) J Occup Environ Med 44(3): 271-281.

PubMed | CrossRef | Others

39. Young, H.A., Maillard, J.D., Levine, P.H., et al. Investigating the risk of cancer in 1990-1991 US Gulf War veterans with the use of state cancer registry data. (2010) Ann Epidemiol 20(4): 265-272.

PubMed | CrossRef | Others
Ommega Online Publishers

Journal Title: Journal of Environment and Health Science (JEHS)

Journal Short Name: J Environ Health Sci
Journal ISSN: 2378-6841

E-mail: environmentalscience@ommegaonline.org

Website: www.ommegaonline.org 